\title{
Additive interaction of gefitinib ('Iressa', ZDI839) and ionising radiation in human tumour cells in vitro
}

\author{
N Giocanti', C Hennequin ${ }^{1,2}$, D Rouillard ${ }^{3}$, R Defrance ${ }^{4}$ and V Favaudon ${ }^{*, 1}$ \\ 'U 612 INSERM \& Institut Curie-Recherche, Laboratoires I I 0-1 | 2, Centre Universitaire, 91405 Orsay, France; '²ancérologie-Radiothérapie, I avenue \\ Claude Vellefeaux, Hôpital Saint-Louis, 75010 Paris, France; ${ }^{3}$ Service de Cytométrie, Institut Curie-Recherche, 26 rue d'Ulm, 75005 Paris, France; \\ ${ }^{4}$ AstraZeneca-France, I place Louis-Renault, 92844 Rueil-Malmaison, France
}

Cultures of human carcinoma A-43I, A-549 and HeLa cells were challenged with $\gamma$-rays without or with concomitant exposure to gefitinib, a potent inhibitor of the tyrosine kinase activity of epidermal growth factor receptor (EGFR). The outcome of treatment was determined from cell and colony count, cell cycle progression and DNA double-strand break formation and rejoining. Apoptosis was measured in parallel from hypodiploid DNA and using an annexin V assay. Gefitinib developed a cytostatic effect in all cell lines, with drug sensitivity correlating the level of EGFR expression. A weak cytotoxicity of gefitinib was observed in HeLa cells only, although the drug was unable to induce significant cell cycle redistribution in this cell line. In contrast, substantial GI block and S-phase depletion was observed in A-43I and A-549 cells exposed to gefitinib. The drug brought about additive to subadditive interaction with radiation with regard to growth inhibition, clonogenic death and induction of apoptosis. Consistently, gefitinib did not hinder the rejoining of radiation-induced DNA double-strand breaks in any cell line. The results demonstrate that gefitinib may elicit cytotoxicity at high concentration, but does not act as a radiosensitiser in vitro in concomitant association with radiation.

British Journal of Cancer (2004) 91, 2026-2033. doi:I0.I038/sj.bjc.6602242 www.bjcancer.com

Published online 16 November 2004

(c) 2004 Cancer Research UK

Keywords: EGFR; gefitinib; ionising radiation; cell cycle; cytotoxicity; apoptosis

The signalling pathways downstream from the epidermal growth factor receptor (EGFR) play a key role in the control of tumour cell proliferation, angiogenesis and metastatic spread. Actually, activation or overexpression of EGFR has been associated with local recurrence and poor prognosis in patients (Nicholson et al, 2001; Gupta et al, 2002; Magné et al, 2002), as well as with resistance to drugs and radiation in murine carcinomas in vivo (Akimoto et al, 1999) and human tumour cells in vitro (SchmidtUllrich et al, 1997; Dent et al, 1999; Chen et al, 2000). Monoclonal antibodies such as cetuximab (IMC-225, Imclone or Erbitux), a human-mouse chimeric antibody directed against the extracellular ligand-binding region of EGFR, and chemical inhibitors of the tyrosine kinase domain of EGFR such as gefitinib ('Iressa', ZD1839), a synthetic anilinoquinazoline, have consistently been designed in hopes that they might downregulate mitogenic pathways and provide enhanced response to cytotoxic drugs or ionising radiation.

Preclinical studies of combined treatment with radiation have been performed with both cetuximab and gefitinib. Enhanced radiation susceptibility by cetuximab was reported in a variety of epithelial tumour cell lines in vitro (Huang and Harari, 2000; Bianco et al, 2002; Culy and Faulds, 2002; Magné et al, 2002; Williams et al, 2002; Solomon et al, 2003). This effect correlated

\section{*Correspondence: Dr V Favaudon;}

E-mail: vincent.favaudon@curie.u-psud.fr

'Iressa' is a trademark of the AstraZeneca group of companies

Received 21 July 2004; revised 15 September 2004; accepted 28 September 2004; published online 16 November 2004 increased radiation-induced apoptosis (Huang et al, 1999; Harari and Huang, 2001; Sclabas et al, 2003) and S-phase depletion (Huang and Harari, 2000; Harari and Huang, 2001). In combination with radiation, gefitinib brought on synergistic antiproliferative and proapoptotic effects in vitro and increased tumour growth delay in the treatment of human tumour xenografts in mouse (Bianco et al, 2002; Culy and Faulds, 2002; Huang et al, 2002; Williams et al, 2002; Solomon et al, 2003).

However, the additivity status of gefitinib-radiation interaction in vitro has not been firmly established. In fact, the determination of additivity is subject to many drawbacks, which are listed below. (i) Contrary to cytotoxic drugs, the equation fitting the dose dependence of radiation survival includes a quadratic term. Isobolic methods, based on the isoeffect concept, have been designed to overcome this difficulty (Steel and Peckham, 1979), but are not relevant here because the cytotoxicity of EGFR inhibitors is weak. (ii) Contact with cytostatic agents, such as EGFR inhibitors, may result in accumulation of cells in a radiosensitive compartment of the cell cycle (Huang and Harari, 2000). (iii) The presence of cell clusters or multiplets introduces large errors in viability measurements with clonogenic assays, and leads to overestimation of radiosensitivity (Rockwell, 1985) particularly in the low dose range of radiation. This may occur in experiments involving prolonged exposure to cytostatic drugs as growth arrest by these drugs is seldom complete. (iv) To overcome this problem, clusters may be dislocated and replated as isolated cells. However, immediate plating following radiation allows expression of the so-called 'potentially lethal damage' and boosts radiation-induced lethality by a large factor (Little et al, 1973). 
(v) A persistent drop of the proliferation rate is frequently observed among radiation survivors.

Taking into account the above pitfalls, we re-evaluated the interaction between gefitinib and radiation in three human tumour cell lines (A-439, A-541, HeLa) differing in EGFR expression, with reproductive cell death, altered cell cycle progression and DNA double-strand break induction and rejoining as end points. The results show that gefitinib may elicit a cytotoxic potential in some cell lines but does not impair radiation recovery.

\section{MATERIALS AND METHODS}

\section{Products}

Gefitinib was kindly provided by AstraZeneca (Rueil-Malmaison, France) as a micronised powder. Aliquots were stored as a $10 \mathrm{~mm}$ stock solution in pure dimethyl sulphoxide (DMSO), and dilutions were made daily in growth medium. The final concentration of DMSO $(0.2 \%)$ was low enough so as not to alter cell growth. Rabbit polyclonal antibody raised against EGFR came from Cell Signaling Technology (Beverly, MA, USA). Protease inhibitors and anti- $\alpha-$ tubulin mouse monoclonal antibody were from Sigma-Aldrich Co. (Saint Quentin Fallavier, France). Goat HRP-conjugated secondary antibodies were from Jackson ImmunoResearch Laboratories (West Grove, PA, USA). All products for cell culture were from Invitrogen (Cergy-Pontoise, France).

\section{Cell lines}

A-431 (human vulvar carcinoma, ATCC CRL-1555; p53 mutated), A-549 (human lung carcinoma, ATCC CCL-185; wild type p53) and HeLa cells (human cervix carcinoma, kindly provided by Dr J Coppey; nonfunctional p53 in relation to HPV16-E6 expression) were grown $\left(37^{\circ} \mathrm{C}, 93 \%\right.$ air with $\left.7 \% \mathrm{CO}_{2}\right)$ as monolayers in RPMI-1640 (A-431, A-549) or Dulbecco's minimal essential medium (HeLa) supplemented each with $10 \%$ foetal calf serum, $100 \mathrm{IU} \mathrm{ml}^{-1}$ penicillin, $0.1 \mathrm{mg} \mathrm{ml}^{-1}$ streptomycin and $0.86 \mathrm{mg} \mathrm{ml}^{-1}$ Glutamax-I.

A-431 cells reportedly express high levels of EGFR (Ullrich et al, 1984; Christensen et al, 2001; Moasser et al, 2001). Epidermal growth factor receptor expression is comparatively low in A-549 (Sirotnak et al, 2000; Moasser et al, 2001) and HeLa cells (Hu et al, 1997; Bandyopadhyay et al, 1998). This was confirmed by Western blot analysis (data not shown) in cells grown under the same conditions ( $10 \%$ foetal calf serum) as used for gefitinib and radiation assays. The relative amounts of EGFR were 15.3 (A-431), 1.0 (A-549) and 1.9 (HeLa).

\section{Irradiation}

$\gamma$-Ray irradiation of cells with or without concomitant exposure to gefitinib was performed at room temperature $\left(21-24^{\circ} \mathrm{C}\right)$ using an IBL-637 $\left({ }^{137} \mathrm{Cs}\right)$ irradiator (CIS-Biointernational). The dose rate was $1.0 \mathrm{~Gy} \mathrm{~min}^{-1}$.
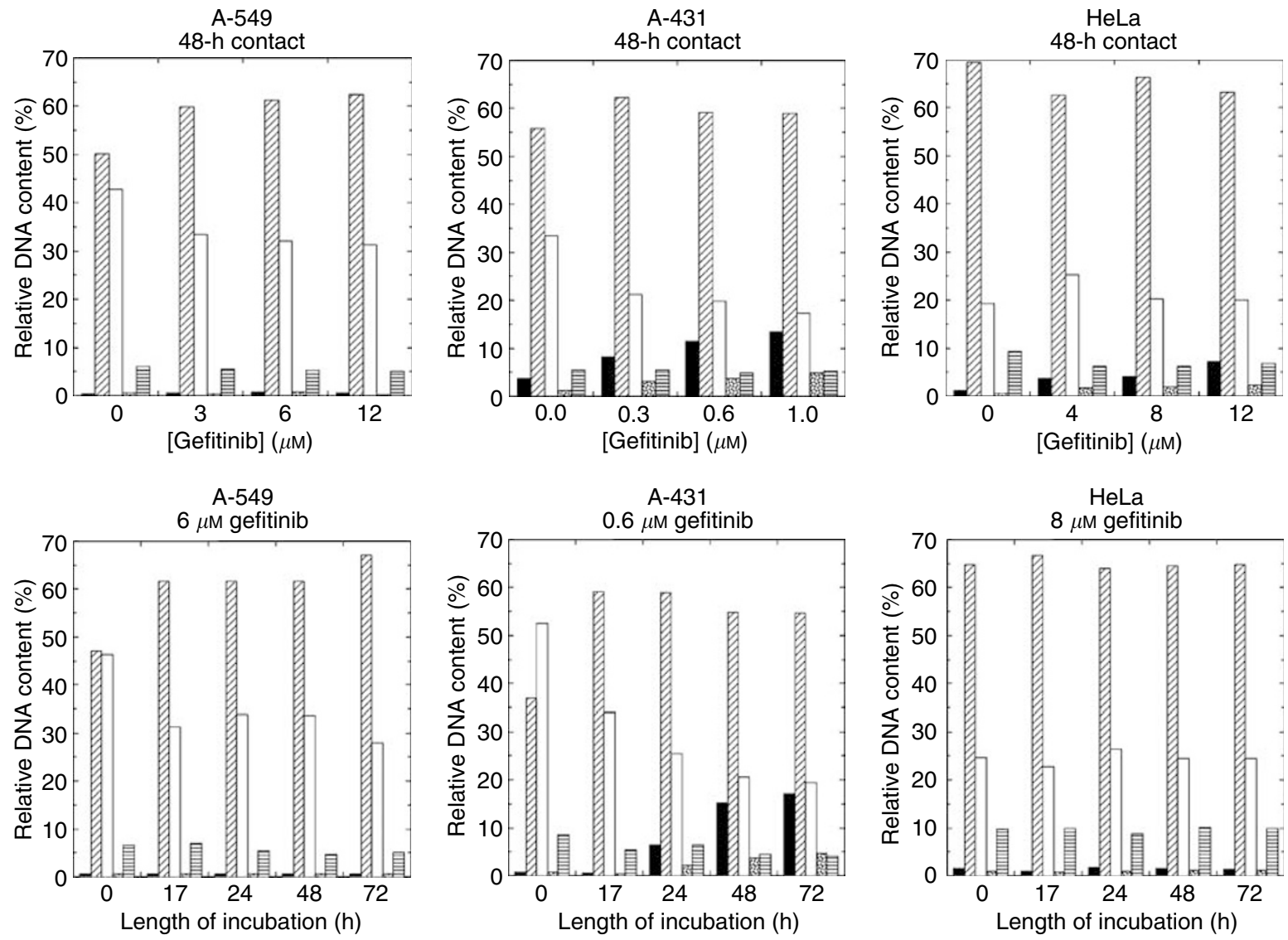

Sub-G1

$$
\square \mathrm{G} 1 \square \mathrm{S} \text { 拨 } \mathrm{Sq} \equiv \mathrm{G} 2-\mathrm{M}
$$

Figure I Altered cell cycle progression by gefitinib. A-549, A-43I and HeLa cells were exposed to various concentrations of gefitinib for up to 5 days. Cells were harvested daily after BrdUrd labelling, fixed and analysed by flow cytometry. Sq is the percentage of cells arrested during $\mathrm{S}$ phase. The top row shows the concentration-dependent drug response after 48-h incubation. The bottom row shows the evolution of the various compartments of the cell cycle in the presence of an $\mathrm{IC}_{50}$ of drug. 


\section{Cytotoxicity and growth inhibition}

The response of cells to radiation (up to $8 \mathrm{~Gy}$ ), gefitinib (up to $19 \mu \mathrm{M}$ ), or a combination of both, was determined using colonyforming assays. Dimethyl sulphoxide $(0.2 \%)$ was present at constant concentration in all experiments. For treatments involving short drug exposure, 800-1000 cells from exponentially growing subcultures were isolated by trypsinisation, plated in triplicate in $25-\mathrm{cm}^{2}$ flasks and incubated at $37^{\circ} \mathrm{C}$ for $4 \mathrm{~h}$ prior to treatment. Following treatment, the flasks were rinsed twice with Hank's balanced salt solution, and cells returned to normal growth medium for 11 or 12 days. Colonies were fixed with methanol, stained and scored visually. The surviving fraction was calculated as the percentage of colonies relative to controls.

As cultures were exposed for $24 \mathrm{~h}$ or more to gefitinib, cells had to be plated after treatment. In combined treatment with $\gamma$-rays, cells were allowed to recover from radiation for $24 \mathrm{~h}$ prior to trypsin, counted and plated at a density of $800-1000$ cells ( $25 \mathrm{~cm}^{2}$ flasks).

For growth inhibition assays, $25 \mathrm{~cm}^{2}$ flasks were seeded with $10^{5}$ cells and incubated for $24 \mathrm{~h}$ prior to introduction of gefitinib. Cells were harvested and counted every day for 8 days after drug, with or without combined irradiation. The drug was renewed every $48 \mathrm{~h}$.

\section{Cell cycle analysis}

Cell cycle progression was monitored by dual-parameter flow cytometry using a FACStar PLUS cytofluorometer (BektonDickinson Biosciences, Le Pont de Claix, France). Cells were grown for 1-6 days with or without gefitinib. At $20 \mathrm{~min}$ before harvesting, cells were incubated with BrdUrd $(10 \mu \mathrm{M})$ for pulse labelling of S-phase cells. Floating and adherent cells were pooled after trypsinisation, and fixed in $70 \%$ ice-cold ethanol. Treatment of fixed cells, data acquisition and processing were performed as described (Demarcq et al, 1992). Cell cycle analysis was performed with ProCyt software (CEA-INSERM, Grenoble, France).

\section{DNA double-strand break determination}

DNA double-strand breaks were measured by neutral filter elution as described (Bradley and Kohn, 1979; Pommier et al, 1984). Cells were labelled with $\left[2-{ }^{14} \mathrm{C}\right]$ thymidine $\left(0.06 \mu \mathrm{Ci} \mathrm{ml}^{-1}\right)$ for $48 \mathrm{~h}$, allowed to ligate Okasaki fragments prior to treatments and sequentially lysed by $0.2 \% \mathrm{~N}$-lauroylsarcosine, $0.2 \mathrm{M} \mathrm{NaCl}$, followed
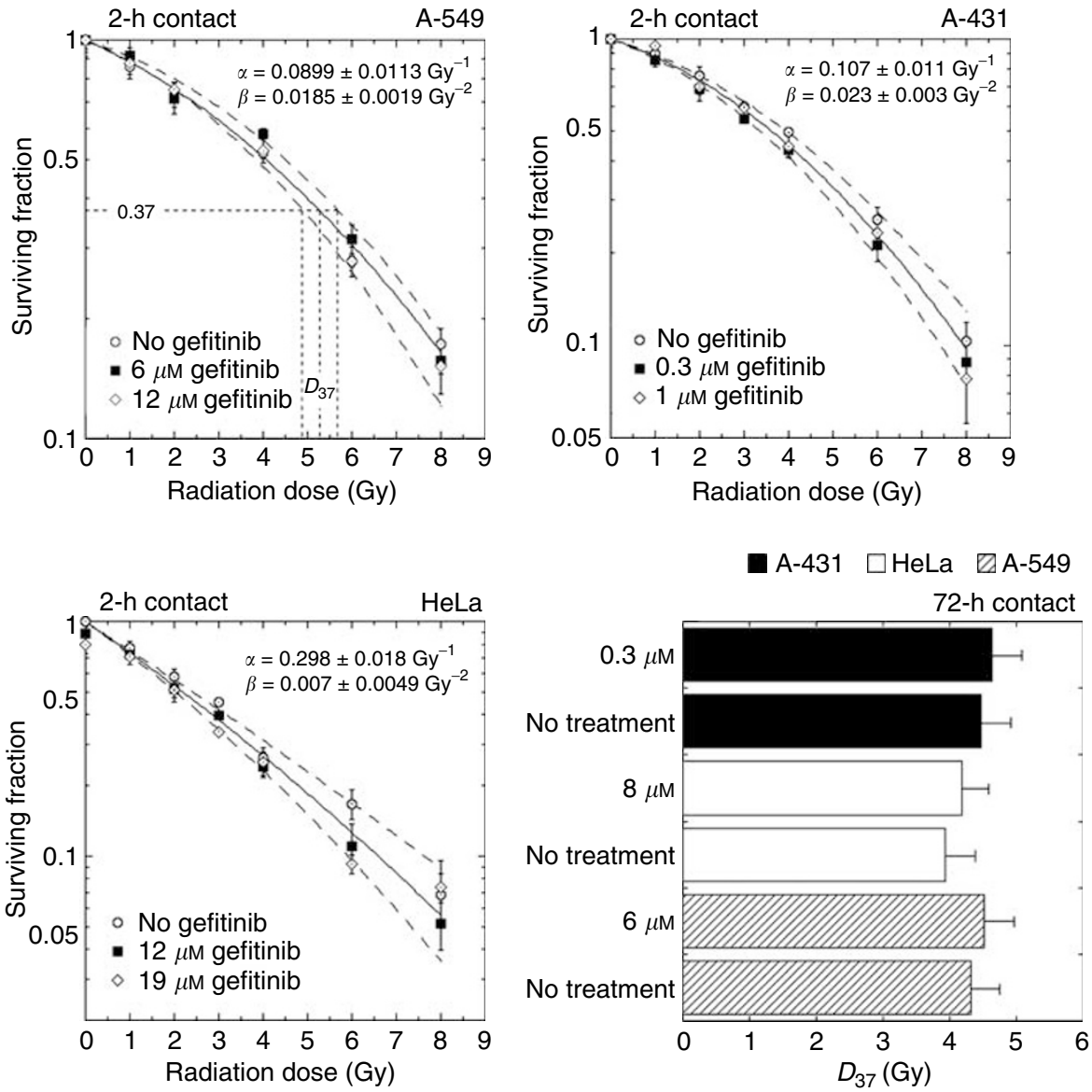

Figure 2 Summary of clonogenic radiation response following short (2-h) and prolonged (72-h) contact with gefitinib. For 2-h contact (survival curves) cells were plated in triplicate before treatment and exposed to gefitinib for I-h preceding and following irradiation. The surviving fraction (S) was fitted to the classical linear-quadratic equation, $\ln S=-\alpha D-\beta D^{2}$, where $D$ is the radiation dose and $\alpha$ and $\beta$ adjustable parameters. Calculations were made through nonlinear least-squares regression taking all data points into account, using Kaleidagraph software (Synergy Software, Reading, PA, USA). Bars represent standard deviation. The dotted lines were drawn according to the linear-quadratic model from the $\alpha_{\max }, \beta_{\text {max }}$ and $\alpha_{\min }, \beta_{\text {min }}$ couples, respectively, and represent the limit of confidence deduced from standard deviation. For HeLa cells, the minor drop in survival at null radiation dose corresponds to the cytotoxicity of gefitinib against this cell line. For 72-h contact (bar diagram, bottom right), cells were exposed for $48 \mathrm{~h}$ to gefitinib, irradiated, incubated with drug for a further $24 \mathrm{~h}$, trypsinised and plated at a suitable density. Survival curves were fitted to the linear-quadratic model. The $D_{37}$ (or $D_{0}$ ) values, that is, the doses that reduce survival to $\mathrm{l} / \mathrm{e}=0.37$ of that in controls, were calculated from these curves (see upper left panel). The results suggest a weak trend to increased radioresistance by gefitinib. 
by $2 \%$ laurylsulphate and $1 \mathrm{mg} \mathrm{ml}^{-1}$ proteinase $\mathrm{K}$ for $30 \mathrm{~min}$. The retention of $\left[{ }^{14} \mathrm{C}\right]$ thymidine-labelled DNA was measured after 20-ml (10-h) elution.

\section{Determination of apoptosis}

Apoptosis was determined on floating and adherent cells using two techniques.

(i) Analysis of DNA fragmentation by flow cytometry: The hypodiploid (sub-G1) fraction was measured using FACS analysis of propidium-iodide-stained cells after overnight fixation with cold $70 \%$ ethanol. The sub-G1 region was determined by a gate on the DNA content histogram excluding the debris at the origin of the abscissa.

(ii) Annexin $V$ assay: Detection of phosphatidylserine on the outer face of the plasma membrane was carried out on fresh cells with FITC-conjugated Annexin V (Oncogene Research Products, San Diego, CA, USA). $10^{6}$ cells were suspended in $1 \mathrm{ml}$ ice-cold binding buffer (10 mM HEPES, $150 \mathrm{~mm} \mathrm{NaCl}$, $2.5 \mathrm{mM} \mathrm{CaCl}_{2}, 1 \mathrm{~mm} \mathrm{MgCl} 2,4 \% \mathrm{BSA}, \mathrm{pH}$ 7.4). A volume of $10 \mu \mathrm{l}$ of media-binding buffer and $1.25 \mu \mathrm{l}$ of Annexin V-FITC $\left(200 \mu \mathrm{g} \mathrm{ml}^{-1}\right)$ were added to $500 \mu \mathrm{l}$ of the cell suspension for $15 \mathrm{~min}$ at room temperature, in the dark. Cells were harvested by centrifugation and resuspended in $0.5 \mathrm{ml}$ cold binding buffer. A first analysis by flow cytometry was immediately performed with cells stained with Annexin V-FITC only. Propidium iodide $\left(10 \mu \mathrm{l} ; 30 \mu \mathrm{g} \mathrm{ml}^{-1}\right.$ in PBS) was subsequently added and analysis of both PI and FITC fluorescence was carried out with CellQuest Pro software (Becton-Dickinson Biosciences) as described (Darzynkiewicz et al, 1997). Cells that bound Annexin V-FITC without propidium iodide staining were considered as early apoptotic cells; necrotic or apoptotic cells in terminal stages were positive for both annexin V-FITC and propidium iodide.

\section{Western blot analysis}

$2 \times 10^{7}$ mid-log growing cells were lysed in $250 \mu$ l RIPA buffer supplemented with $1 \mathrm{~mm}$ phenylmethanesulphonyl fluoride plus protease inhibitors. Proteins were titrated using the Bio-Rad's DC protein assay (Bio-Rad, Hercules, CA, USA). After SDS-polyacrylamide gel electrophoresis, the proteins were blotted onto nitrocellulose membrane (Scleicher \& Schuell, Dassel, Germany), incubated with specific primary and secondary antibodies and revealed using an ECL kit. The densitometric analysis of films was carried out with the aid of QuantityOne software (Bio-Rad).

\section{RESULTS}

\section{Growth inhibition and cell cycle redistribution by gefitinib}

Cells were incubated in the presence of increasing concentrations of gefitinib for up to 8 days, and growth measured by cell count relative to untreated samples. Gefitinib alone produced a concentration-dependent inhibition of cell proliferation in the three cell lines. $\mathrm{IC}_{50}$, that is, the drug concentration that reduced growth to $50 \%$ of that in controls (5-days contact with drug) was $0.3,6$ and $8 \mu \mathrm{m}$ for A-431, A-549 and HeLa cells, respectively.

Cell cycle disruption by gefitinib was investigated by flow cytometry as a function of both the drug concentration and length of incubation. Gefitinib brought about G1-phase accumulation and S-phase depletion in A-549 and A-431 cells only (Figure 1). Above the $\mathrm{IC}_{50}$, the strength of this effect depended more on the length of contact with the drug than on the drug concentration, and was as anticipated from earlier studies (Bianco et al, 2002; Huang et al, 2002; Solomon et al, 2003). In addition, substantial accumulation of hypodiploid (sub-G1) nuclei was observed specifically in A-431 cells in proportion to the drug concentration and the length of incubation (see below). Minor amounts of hypodiploid nuclei were also observed in HeLa cells, although gefitinib did not perturb cell cycle progression in this cell line.

\section{Cytotoxicity of gefitinib and phenotype alteration}

The cytotoxic potential of gefitinib in short exposure (2-h), was assessed by clonogenic assays in the three cell lines of interest. No
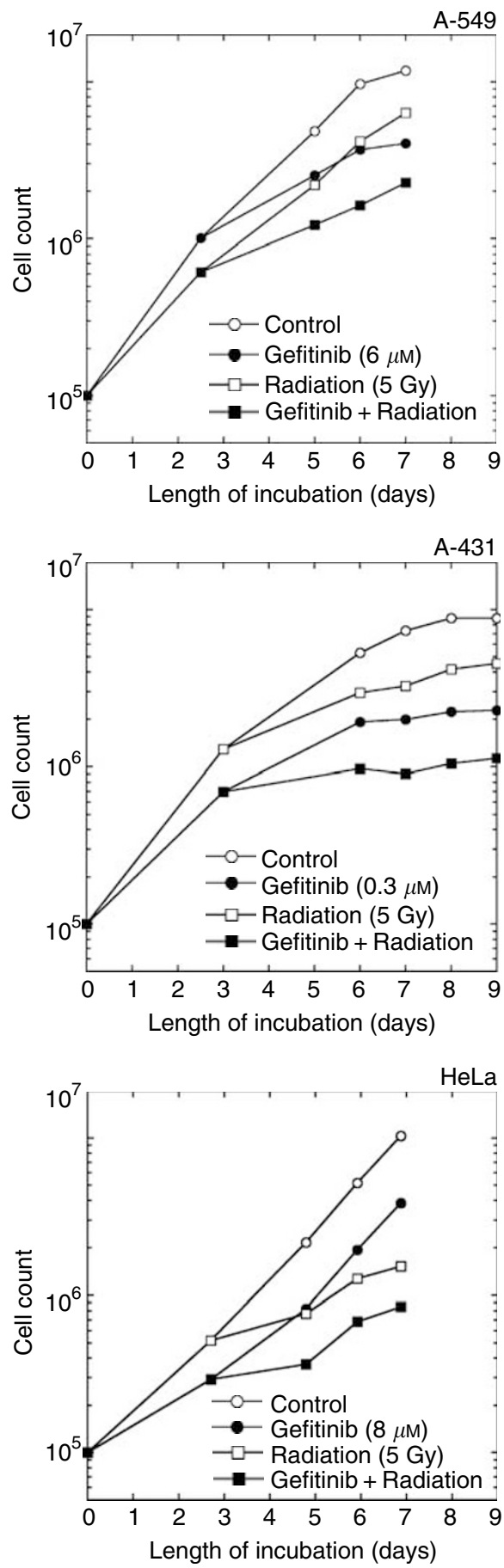

Figure 3 Growth inhibition by gefitinib and radiation. Cells were exposed to gefitinib for $48 \mathrm{~h}$, irradiated and subsequently incubated with gefitinib for up to 7 days. Note that radiation survivors did not recover a full growth potential. Gefitinib induced an additional cytostatic effect, in such a way that growth curves with and without drug were parallel. 
cytotoxicity was observed in A-431 and A-549 cells. In contrast, gefitinib developed weak, concentration-dependent cytotoxicity $\left(\mathrm{IC}_{50} \approx 51 \mu \mathrm{M}\right)$ against HeLa cells.

Prolonged contact with gefitinib at high concentration resulted in marked alterations in cell morphology. Cells flattened with an increased cytoplasm-to-nucleus surface ratio by a factor of $2.0 \pm 0.3$, and A-549 and A-431 cells at the periphery of colonies extended large lamellipodes. This might explain why, in a few instances, a substantial part of cells was killed by trypsin after prolonged exposure to gefitinib.

\section{Effect of gefitinib on radiation survival: clonogenic assays}

To determine whether gefitinib was able to alter radiation survival, cells were exposed to gefitinib for $1 \mathrm{~h}$, irradiated and returned to the incubator for a further $1 \mathrm{~h}$ in the presence of drug. No modification of radiation response was observed in any of the three cell lines (Figure 2).

A different protocol was used to study the effect of prolonged contact $(>24 \mathrm{~h})$ with gefitinib. In that case, cells were trypsinised and plated at a known density long enough after irradiation $(24 \mathrm{~h})$ to allow the repair of potentially lethal damage. No significant difference was observed between radiation alone and combined treatment, though a trend towards a minor increase of radio-

Table I Cell proliferation relative to control for gefitinib, radiation or a combination of both

\begin{tabular}{llccc}
\hline & Treatment & A-43 I & A-549 & HeLa \\
\hline a & Gefitinib & $0.253(0.3 \mu \mathrm{M})$ & $0.343(6 \mu \mathrm{M})$ & $0.470(8 \mu \mathrm{M})$ \\
b & Radiation $(5 \mathrm{~Gy})$ & 0.473 & 0.538 & 0.161 \\
c & Product $a \times b$ & 0.120 & 0.184 & 0.076 \\
d & Combined treatment & 0.119 & 0.192 & 0.082 \\
\hline
\end{tabular}

Treatments were as in Figure 4, and cells were counted at day 7 after the beginning of treatment.
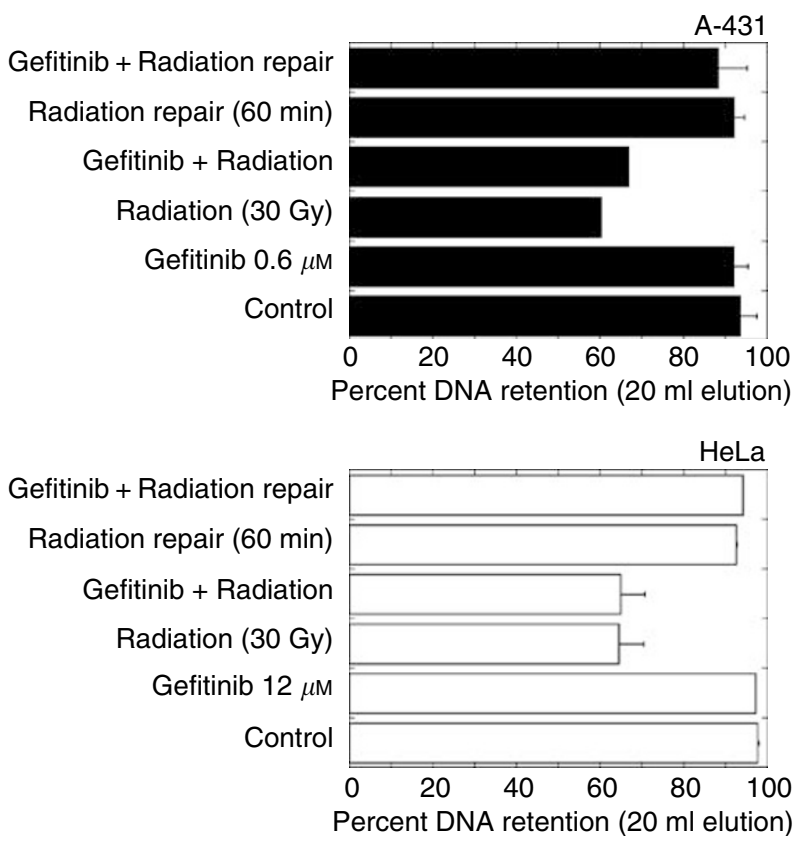

Figure 4 Neutral elution analysis of DNA double-strand break formation and repair after exposure to gefitinib (3-h contact), irradiation (30 Gy) or a combination of both. In combined treatment, cells were exposed to gefitinib for $2 \mathrm{~h}$, irradiated and lysed immediately or after I-h recovery at $37^{\circ} \mathrm{C}$. Each experiment was performed in duplicate. Bars, mean deviation. resistance was noted (Figure 2). Finally, no change in radiosensitivity was observed as the length of drug contact preceding and following irradiation was raised from 1 to $48 \mathrm{~h}$.

\section{Effect of gefitinib on radiation survival: growth inhibition}

Plated cells were allowed to grow for $24 \mathrm{~h}$, then incubated for $48 \mathrm{~h}$ with gefitinib, irradiated and harvested after an additional 1-6days incubation in the presence of gefitinib at the same concentration. The cell count was monitored daily.

Figure 3 shows the results from cells exposed to an $\mathrm{IC}_{50}$ of gefitinib. Gefitinib exerted a cytostatic effect, as expected. Persistent attrition of the reproductive potential, in addition to induced kill, was observed in irradiated cells. This, notwithstanding cell proliferation relative to control in combined treatment, matched exactly the product of the growth-inhibitory effects of radiation and gefitinib applied independently, indicating strict additivity (Table 1)

\section{Effect of gefitinib on DNA double-strand break induction or repair}

Epidermal growth factor receptor-dependent transduction has been reported to generate activation, enhance transcription and nuclear translocation of DNA-dependent protein kinase (DNA-PK) in A-431, HeLa and SCC-13Y cells (Bandyopadhyay et al, 1998; Huang et al, 2002). Cetuximab has also been reported to trigger
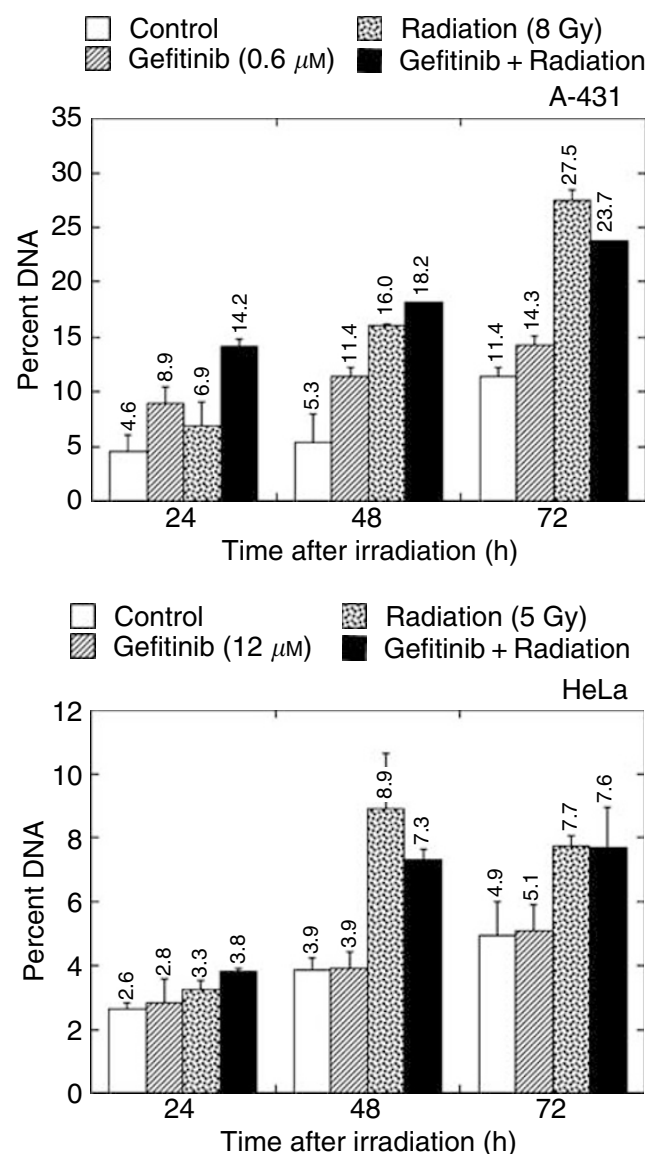

Figure 5 Flow cytometric analysis of the hypodiploid (sub-GI) DNA content in A-43I and HeLa cells exposed to gefitinib, radiation or a combination of both. Cells were exposed to gefitinib for $60 \mathrm{~h}$, irradiated, returned to the incubator in the presence of gefitinib and collected at the times indicated. Mock-irradiated samples were collected after the same length of incubation. 

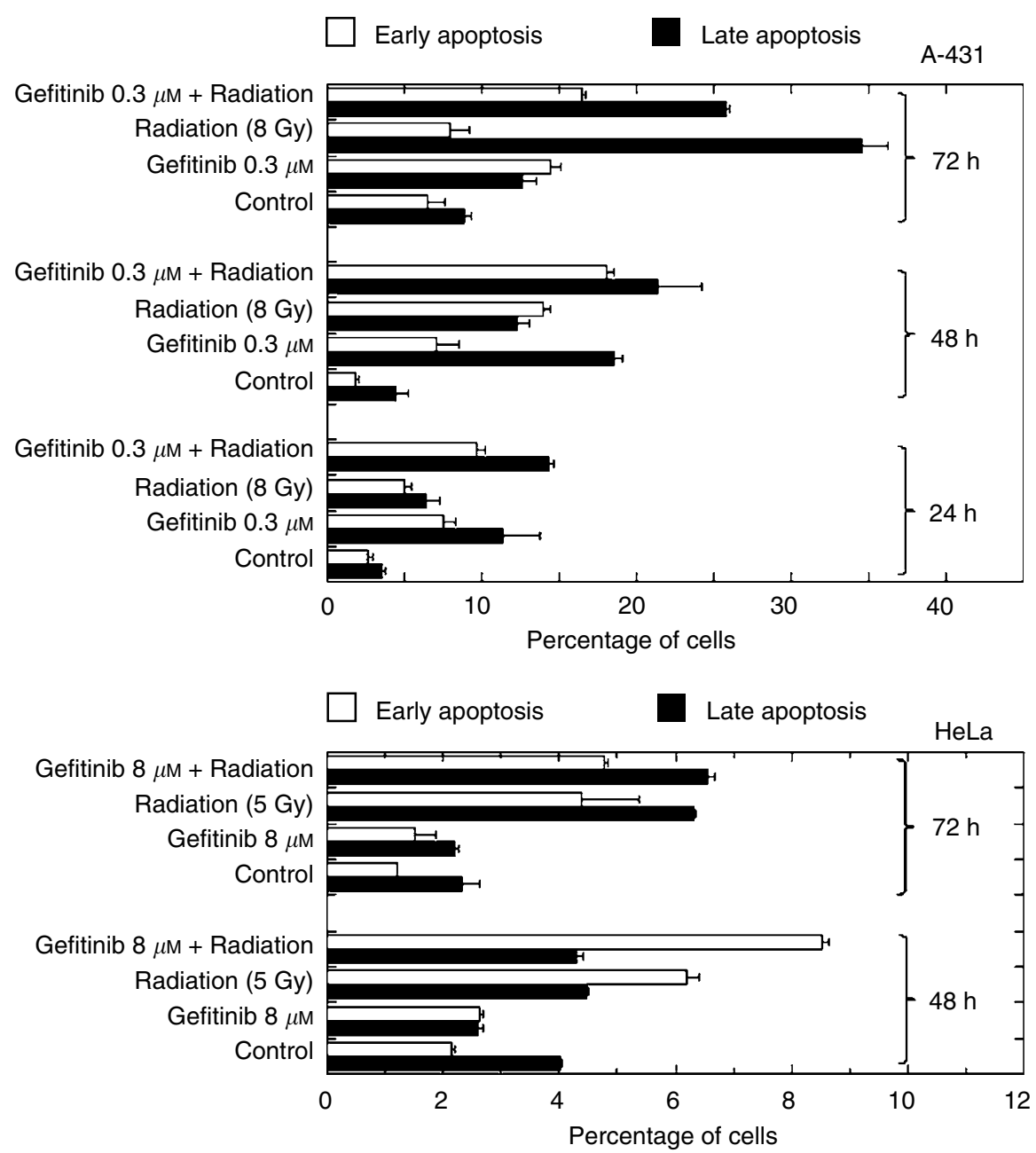

Figure 6 Annexin V-FITC analysis of apoptosis in A-43I and HeLa cells. Cells were exposed to gefitinib for $60 \mathrm{~h}$, irradiated, returned to the incubator in the presence of gefitinib and collected at the times indicated. Nonirradiated, drug-free controls were collected after the same length of incubation. The distinction between early and late apoptosis was made as described (Darzynkiewicz et al, 1997).

binding of EGFR to the heterotrimeric DNA-PK complex in the cytoplasmic fraction and deplete the nuclear pool of DNA-PK (Bandyopadhyay et al, 1998). Whether this elicits impaired DSB repair and increased radiation susceptibility in vivo is open to question, as phase I studies did not show limiting toxicity of cetuximab in association with radiotherapy against advanced head and neck cancer (Robert et al, 2001). It may be best to consider that nuclear exclusion of DNA-PK results from S-phase depletion by the antibody. Actually, cetuximab causes a marked G1 block (Huang and Harari, 2000), while nuclear import and activation of DNA-PKcs occur only in S phase and at the G1/S junction (Lee et al, 1997; Nilsson et al, 1999). Gefitinib might induce the same effect.) As DNA-PK plays a key role in DNA double-strand break repair through NHEJ, the effect of gefitinib on the rejoining of radiation-induced breaks was investigated by neutral filter elution. Gefitinib alone did not induce any DNA damage. When tested in A-431 and HeLa cells, gefitinib had no effect on the incidence or rejoining of DNA double-strand breaks (Figure 4).

\section{Apoptosis in combined treatment with radiation and gefitinib}

Apoptosis by gefitinib without and with combined exposure to radiation was investigated in the three cell lines. No apoptosis was detected in A-549 cells, confirming that A-549 cells are resistant to this mode of cell death (Lawrence et al, 2001; Stuschke et al, 2002).
Therefore, the results presented below are for A-431 and HeLa cells only. Two methods were used to assess apoptosis. In each instance, cells were pre-incubated for $48 \mathrm{~h}$ with an $\mathrm{IC}_{50}$ of gefitinib, prior to $\gamma$-ray irradiation. Irradiated cells were collected after a further 24-, 48- or 72-h incubation, long after completion of DNA repair.

(i) Gefitinib generated hypodiploid (sub-G1) nuclei in A-431 and HeLa cells, though to a much lower extent in the latter. Ionising radiation also induced an increase of the sub-G1 fraction. In both cell lines, combined treatment produced additive interaction at $24 \mathrm{~h}$. In contrast, infra-additive interaction was observed at 48 and $72 \mathrm{~h}$ of post-irradiation incubation in both cell lines (Figure 5).

(ii) FACS analysis of annexin V-FITC binding to the cells' plasma membrane correlated with the sub-G1 content (Figure 6). Gefitinib alone induced significant apoptosis above background in A-431 cells only. Radiation-induced apoptosis was observed in both A-431 and HeLa cells, but combined treatment did not promote apoptosis. In A-431 cells, nearly additive interaction was observed at $24 \mathrm{~h}$, but infra-additive interaction occurred at 48 and $72 \mathrm{~h}$ of post-irradiation incubation in both cell lines.

\section{DISCUSSION}

We found that short (2-h) exposure to gefitinib had no effect on radiation response in clonogenic assays, and strictly additive 
interaction was observed (Figures 2 and 3) after 72-h contact with gefitinib. Consistently, gefitinib did not impair DNA double-strand break rejoining (Figure 4) and did not interfere with the radiationinduced G2-M block (data not shown). In our hands, gefitinib and radiation acted additively to induce apoptosis in A-431 and $\mathrm{HeLa}$ cells after 24-h contact with drug, whereas the interaction was infra-additive (possibly antagonistic) after more prolonged exposure (Figures 5 and 6). However, significant amounts of gefitinib-induced apoptosis were observed in A-431 cells only. In spite of the fact that HeLa cells elicited cytotoxic response to gefitinib, drug-induced apoptosis in HeLa cells was below 5\%; A549 cells did not show evidence of apoptosis. Accordingly, the apoptotic potential and the growth-inhibitory efficiency of gefitinib are not inter-related in the three cell lines used.

HeLa cells did not show significant cell cycle redistribution by gefitinib. In contrast, and in agreement with others (Bianco et al, 2002; Huang et al, 2002; Williams et al, 2002), we observed that in A-431 and A-549 cells gefitinib induced accumulation in G1 at the expense of $S$ phase. Moreover, radiation potentiated growth arrest by the drug (Figures 1 and 4). S phase has long been known to be the most radioresistant compartment of the cell cycle (Terasima and Tolmach, 1963). Therefore, as pointed out by Huang and Harari (2000), S-phase depletion by gefitinib could eventually lead to increased radiosensitivity in cells responding to gefitinib. Indirect evidence in favor of this scheme was provided by Wollman et al (1994), who showed that stimulation of MCF-7 cells by extraneously added EGF produced a substantial increase in both S-phase content and radioresistance. However, despite significant S-phase depletion in A-431 and A-549 cells (Figure 1), no radiosensitisation was observed after 72 -h contact with gefitinib (Figure 3).

In conclusion, gefitinib at cytostatic concentration did not impair the rejoining of radiation-induced DNA double-strand breaks, and brought about additive interaction with radiation in terms of growth inhibition or induced cell death in A-431, A-549 and HeLa cells. Such additivity may be beneficial in chemo-

\section{REFERENCES}

Akimoto T, Hunter NR, Buchmiller L, Mason K, Ang KK, Milas L (1999) Inverse relationship between epidermal growth factor receptor expression and radiocurability of murine carcinomas. Clin Cancer Res 5: $2884-2890$

Balosso J, Minne JF, Touboul E (1995) Late complications of chemoradiotherapeutic combinations: fundamental aspects and clinical experience. Bull Cancer Radiothér 82: $101-112$

Bandyopadhyay D, Mandal M, Adaam L, Mendelsohn J, Kumar R (1998) Physical interaction between epidermal growth factor receptor and DNA-dependent protein kinase in mammalian cells. J Biol Chem 273: $1568-1573$

Bianco C, Bianco R, Tortora G, Damiano V, Guerrieri P, Montemaggi P, Mendelsohn J, De Placido S, Bianco A, Ciardello F (2000) Antitumor activity of combined treatment of human cancer cells with ionizing radiation and anti-epidermal growth factor receptor monoclonal antibody C225 plus type I protein kinase A antisense oligonucleotide. Clin Cancer Res 6: 4343-4350

Bianco C, Tortora G, Bianco R, Caputo R, Veneziani BM, Damiano V, Troiani T, Fontanini G, Raben D, Pepe S, Bianco AR, Ciardiello F (2002) Enhancement of antitumor activity of ionizing radiation by combined treatment with the selective epidermal growth factor receptor-tyrosine kinase inhibitor ZD1839 (Iressa). Clin Cancer Res 8: 3250-3258

Bradley MO, Kohn KW (1979) X-ray induced DNA double-strand-break production and repair in mammalian cells as measured by neutral filter elution. Nucleic Acids Res 7: $793-804$

Brown JM (2001) Therapeutic targets in radiotherapy. Int J Radiat Oncol Biol Phys 49: 319-326

Buchsbaum DJ, Bonner JA, Grizzle WE, Stackhouse MA, Carpenter M, Hicklin DJ, Bohlen P, Raisch KP (2002) Treatment of pancreatic cancer radiotherapeutic combination. Indeed, supra-additive interaction may lead to acute hypertoxicity, reduction of the maximum tolerated doses of both drug and radiation and treatment failure. Contrary to a widely held opinion, radiosensitisation should be considered with care when it comes to eliciting inhibition of radiation recovery (Balosso et al, 1995). Well-known examples of limiting toxicities are from adriamycin (Mayer et al, 1976) and bleomycin (Peters et al, 1988).

It should be recalled here that the most useful mechanisms in chemo-radiotherapeutic combinations are spatial cooperation, reoxygenation and inhibition of tumour repopulation. Reduction in tumour volume after chemotherapy, when it occurs, may result in improved blood supply to the tumour, leading to reoxygenation and increased radiosensitivity. Furthermore, inhibition of neoangiogenesis may lead to increased radiocurability (Brown, 2001; Hennequin and Favaudon, 2002), and in fact recent studies have convincingly shown that both cetuximab and gefitinib are able to afford potentiation of radiotherapy and inhibition of neoangiogenesis in human tumour xenografts in mice (Bianco et al, 2000, 2002; Huang and Harari, 2000; Milas et al, 2000; Buchsbaum et al, 2002; Huang et al, 2002; Williams et al, 2002). This might allow gefitinib and radiotherapy to be used concomitantly or in close temporal proximity to take advantage of inhibition of tumour neoangiogenesis or altered cell cycle distribution, without the acute or late healthy tissue complications that are at risk with inhibition of DNA repair.

\section{ACKNOWLEDGEMENTS}

Thanks are due to Dr J Coppey (Institut Jacques-Monod, Paris) for the generous gift of HeLa cells. This work was supported by financial aid from the Institut Curie and the Institut National de la Santé et de la Recherche Médicale, and by a grant from AstraZeneca. xenografts with Erbitux (IMC-C225) anti-EGFR antibody, gemcitabine, and radiation. Int J Radiat Oncol Biol Phys 54: 1180-1193

Chen Z, Ke LD, Yuan XH, Adler-Storthz K (2000) Correlation of cisplatin sensitivity with differential alteration of EGFR expression in head and neck cancer cells. Anticancer Res 20: 899-902

Christensen JG, Schreck RE, Chan E, Wang X, Yang C, Liu L, Cui J, Sun L, Wei J, Cherrington JM, Mendel DB (2001) High levels of HER-2 expression alter the ability of epidermal growth factor receptor (EGFR) family tyrosine kinase inhibitors to inhibit EGFR phosphorylation in vivo. Clin Cancer Res 7: 4230-4238

Culy CR, Faulds D (2002) Gefitinib. Drugs 62: 2237-2248

Darzynkiewicz Z, Juan G, Li X, Gorczyca W, Murakami T, Traganos F (1997) Cytometry in cell necrobiology: analysis of apoptosis and accidental cell death (necrosis). Cytometry 27: 1-20

Demarcq C, Bastian G, Remvikos Y (1992) BrdUrd/DNA flow cytometry analysis demonstrated cis-diamine-dichloroplatinum (II)-induced cell cycle modifications on human lung carcinoma cells. Cytometry 13: $416-422$

Dent P, Reardon D, Park J, Bowers G, Logsdon C, Valerie K, SchmidtUllrich R (1999) Radiation-induced release of transforming growth factor a activates the epidermal growth factor receptor and mitogen-activated protein kinase pathway in carcinoma cells, leading to increased proliferation and protection from radiation-induced cell death. Mol Biol Cell 10: 2493-2506

Gupta AK, McKenna WG, Weber CN, Feldman MD, Goldsmith JD, Mick R, Machtay M, Rosenthal DI, Bakanauskas VJ, Cerniglia GJ, Bernhard EJ, Weber RS, Muschel RJ (2002) Local recurrence in head and neck cancer: relationship to radiation resistance and signal transduction. Clin Cancer Res 8: $885-892$ 
Harari PM, Huang SM (2001) Head and neck cancer as a clinical model for molecular targeting of therapy: combining EGFR blockade with radiation. Int J Radiat Oncol Biol Phys 49: 427-433

Hennequin C, Favaudon V (2002) Biological basis for chemo-radiotherapy interactions. Eur J Cancer 38: 223 - 230

Hu G, Liu W, Mendelsohn J, Ellis LM, Radinsky R, Andreeff M, Deisseroth AB (1997) Expression of epidermal growth factor receptor and human papillomavirus E6/E7 proteins in cervical carcinoma cells. J Natl Cancer Inst 89: $1271-1276$

Huang SM, Bock JM, Harari PM (1999) Epidermal growth factor receptor blockade with C225 modulates proliferation, apoptosis, and radiosensitivity in squamous cell carcinomas of the head and neck. Cancer Res 59: $1935-1940$

Huang SM, Harari PM (2000) Modulation of radiation response after epidermal growth factor receptor blockade in squamous cell carcinomas: inhibition of damage repair, cell cycle kinetics, and tumor angiogenesis. Clin Cancer Res 6: 2166-2174

Huang SM, Li J, Armstrong EA, Harari PM (2002) Modulation of radiation response and tumor-induced angiogenesis after epidermal growth factor receptor inhibition by ZD1839 (Iressa). Cancer Res 62: 4300-4306

Lawrence TS, Davis MA, Hough A, Rehemtulla A (2001) The role of apoptosis in $2^{\prime}, 2^{\prime}$-difluoro- $2^{\prime}$-deoxycytidine (gemcitabine)-mediated radiosensitization. Clin Cancer Res 7: 314-319

Lee SE, Mitchell RA, Cheng A, Hendrickson EA (1997) Evidence for DNAPK-dependent and -independent DNA double-strand break repair pathways in mammalian cells as a function of the cell cycle. Mol Cell Biol 17: 1425 - 1433

Little JB, Hahn GM, Frindel E, Tubiana M (1973) Repair of potentially lethal radiation damage in vitro and in vivo. Radiology 106: 689-694

Magné N, Fischel JL, Dubreuil A, Formento P, Marcié S, Lagrange JL, Milano G (2002) Sequence-dependent effects of ZD1839 (Iressa) in combination with cytotoxic treatment in human head and neck cancer. Br J Cancer 86: 819-827

Mayer EG, Poulter CA, Aristizabal SA (1976) Complications of irradiation related to apparent drug potentiation by adriamycin. Int J Radiat Oncol Biol Phys 1: $1179-1188$

Milas L, Mason K, Hunter N, Petersen S, Yamakawa M, Ang K, Mendelsohn J, Fan Z (2000) In vivo enhancement of tumor radioresponse by C225 antiepidermal growth factor receptor antibody. Clin Cancer Res 6: 701-708

Moasser MM, Basso A, Averbuch SD, Rosen N (2001) The tyrosine kinase inhibitor ZD1839 ('Iressa') inhibits HER2-driven signaling and suppresses the growth of HER2-overexpressing tumor cells. Cancer Res 61: $7184-7188$

Nicholson RI, Gee JM, Harper ME (2001) EGFR and cancer prognosis. Eur J Cancer 37(Suppl 4): S9-S15

Nilsson A, Sirzen F, Lewensohn R, Wang N, Skog S (1999) Cell cycledependent regulation of the DNA-dependent protein kinase. Cell Prolif 32: $239-248$

Peters LJ, Harrison ML, Dimery IW, Fields R, Goepfert H, Oswald MJ (1988) Acute and late toxicity associated with sequential bleomycin- containing chemotherapy regimens and radiation therapy in the treatment of carcinoma of the nasopharynx. Int J Radiat Oncol Biol Phys 14: $623-633$

Pommier Y, Schwartz RE, Kohn KW, Zwelling LA (1984) Formation and rejoining of DNA double-strand breaks induced in isolated cell nuclei by antineoplastic intercalating agents. Biochemistry 23: 3194-3201

Robert F, Ezekiel MP, Spencer SA, Meredith RF, Bonner JA, Khazaeli MB, Saleh MN, Carey D, LoBuglio AF, Wheeler RH, Cooper MR, Waksal HW (2001) Phase I study of anti-epidermal growth factor receptor antibody cetuximab in combination with radiation therapy in patients with advanced head and neck cancer. J Clin Oncol 19: 3234-3243

Rockwell S (1985) Effects of clumps and clusters on survival measurements with clonogenic assays. Cancer Res 45: $1601-1607$

Schmidt-Ullrich R, Mikkelsen R, Dent P, Todd D, Valerie K, Kavanagh B, Contessa J, Rorrer W, Chen P (1997) Radiation-induced proliferation of the human A431 squamous carcinoma cells is dependent on EGFR tyrosine phosphorylation. Oncogene 15: 1191-1197

Sclabas GM, Fujioka S, Schmidt C, Fan Z, Evans DB, Chiao PJ (2003) Restoring apoptosis in pancreatic cancer cells by targeting the nuclear factor-kappaB signaling pathway with the anti-epidermal growth factor antibody IMC-C225. I Gastrointest Surg 7: 37-43

Sirotnak FM, Zakowski MF, Miller VA, Scher HI, Kris MG (2000) Efficacy of cytotoxic agents against human tumor xenografts is markedly enhanced by coadministration of ZD1839 (Iressa), an inhibitor of EGFR tyrosine kinase. Clin Cancer Res 6: 4885-4892

Solomon B, Hagekyriakou J, Trivett MK, Stacker SA, McArthur GA, Cullinane C (2003) EGFR blockade with ZD1839 ('Iressa') potentiates the antitumor effects of single and multiple fractions of ionizing radiation in human A431 squamous cell carcinoma. Int J Radiat Oncol Biol Phys 55: $713-723$

Steel GG, Peckham MJ (1979) Exploitable mechanisms in combined radiotherapy-chemotherapy: the concept of additivity. Int $\mathrm{J}$ Radiat Oncol Biol Phys 5: 85-91

Stuschke M, Sak A, Wurm R, Sinn B, Wolf G, Stüben G, Budach V (2002) Radiation-induced apoptosis in human non-small-cell-lung cancer cell lines is secondary to cell-cycle progression beyond the G2-phase checkpoint. Int J Radiat Biol 78: 807 -819

Terasima T, Tolmach LJ (1963) Variations in several responses of HeLa cells to X-irradiation during the division cycle. Biophys J 3: 11-33

Ullrich A, Coussens L, Hayflick JS, Dull TJ, Gray A, Tarn AW, Lee J, Yarden Y, Liberma TA, Schlessinger J (1984) Human epidermal growth factor receptor cDNA sequence and aberrant expression of the amplified gene in A431epidermoid carcinoma cells. Nature 309: 418-425

Williams KJ, Telfer BA, Stratford IJ, Wedge SR (2002) ZD1839 ('Iressa'), a specific oral epidermal growth factor receptor-tyrosine kinase inhibitor, potentiates radiotherapy in a human colorectal cancer xenograft model. Br J Cancer 86: $1157-1161$

Wollman R, Yahalom J, Maxy R, Pinto J, Fuks Z (1994) Effect of epidermal growth factor on the growth and radiation sensitivity of human breast cancer cells in vitro. Int J Radiat Oncol Biol Phys 30: 91 - 98 